6. Яблонський В. А. Біотехнологія відтворення тварин. К: Арістей, 2004. 293 c.

7. Bouman A., Heineman M. J., Faas M. M. Sex hormones and the immune response in humans. Human Reproduction Update. 2005. Vol. 11. №4. P. 411-423.

8. Mann G.E. Corpus luteum size and plasma progesterone concentration in cows. Animal Reprod. Sci. 2009. Vol. 115. P. 296-299.

9. Spicer L.J., Zinn S.A. Relationship between concentrations of cortisol in ovarian follicular fluid and varions biochemical markers of follicular differ-entiation in cyclic and anovulatory cattle. J. Animal Sci. 2006. Vol 2. P. 2001-2017.

DOI https://doi.org/10.30525/978-9934-26-111-4-62

\title{
МІКОТОКСИНИ У ЗЕРНІ ЗЛАКОВИХ КУЛЬТУР ТА НЕОБХІДНІСТЬ ЇХ КОНТРОЛЮ
}

\section{Чорнолата Л. П.}

кандидат сільськогосподарських наук, старший науковий співробітник, завідувач лабораторії моніторингу якості, безпеки кормів та сировини

Інститут кормів та сільського господарства Поділля

Національної академії аграрних наук Украӥни

\section{Гуцол Н. В.}

кандидат сільськогосподарських наук, старший науковий співробітник лабораторії моніторингу якості, безпеки кормів та сировини Інститут кормів та сільського господарства Поділля Національної академії аграрних наук України

\section{Мисенко О. О.}

кандидат сільськогосподарських наук, старший науковий співробітник лабораторії моніторингу якості, безпеки кормів та сировини Інститут кормів та сільського господарства Поділля Національної академії аграрних наук України м. Вінниця, Україна

Злакові зернові корми містять невелику кількість сирого протеїну (55-80г на 1 кормову одиницю). Основна маса їх сухої речовини 
представлена вуглеводами, тоді як зерно бобових містить у своєму складі значно більшу кількість сирого протеїну і порівняно невелику кількість вуглеводів. Перетравність зернофуражу досить висока 7590\%. Зерно кукурудзи порівняно з зерном інших злаків бідне на вміст протеїну 7-10\%, прикрість також у тому, що більша його половина представлена білком зеіном, у якому низький вміст амінокислот лізину і триптофану [1, с.145, 2, с. 5].

Основна умова зберігання зерна злакових культур - це забезпечення вмісту вологи до $15 \%$ і дотримання відповідних умов. Що до зберігання зерна кукурудзи то воно пов'язане з певними труднощами, адже його вологість на період збирання досягає $30-40 \%$ і більше. При такій вологості зерно швидко зігрівається, уражається грибами і стає непридатним для використання у годівлі тварин [1, с. 355].

Доброякісний корм, перш за все, повинен бути вільним від небезпечних речовин, які можна поділити на дві групи, це природні компоненти кормів, що виявляють небезпечну дію і шкідливі речовини, які потрапляють у корми зовні.

До останніх відносяться важкі метали, пестициди, нітрати i нітрити, радіонуклиди, а також речовини біологічної природи мікотоксини - низькомолекулярні вторинні метаболіти, які виробляються мікроскопічними пліснявими грибами. Найбільш поширені з них: афлатоксин (В1, В2, G1, G2, та інші); дезоксиніваленон (ДОН); зеараленон (ЗЕА); фумонізин; охратоксин А (ОТА); Т-2 токсин [3, с. 27].

Державні стандарти на корми та кормову сировину у своєму змісті містять дані про допустимі рівні цих небезпечних речовин. Дія мікотоксинів на організм грунтується на їх здатності пригнічувати синтез білка та нуклеїнових кислот; індукувати перекисне окислення ліпідів та апоптоз; порушувати структуру клітинних мембран. Наявність їх у кормах навіть у залишкових кількостях, що не перевищують 100 мкг/кг, може привести до істотних збитків через погіршення продуктивності, відтворної здотності, імунного стану. Важливо пам'ятати, що ці токсичні речовини можуть накопичуватися у організмі і не лише тваринному. Заслуговує на увагу той факт, що встановлено зв'язок інфекційних захворювань з забрудненням кормів мікотоксинами. Так доведено, що спалахи ензоотій у птахогосподарствах більш ніж у 90\% випадків виникали при забрудненні кормів мікотоксинами [4, с.601].

В Україні при оцінці якості кормів постійно використовують показник ступінь токсичності (нетоксичний, слаботоксичний, 
токсичний), який інформує про безпечність фуражного зерна, продуктів його переробки і комбікорму [5, с. 10]. Нажаль даний показник надає загальну інформацію, яка не дає змоги поставити точний діагноз, оцінити ситуацію та прийняти оптимальні рішення, як для лікування так і для профілактики захворювань тварин.

У лабораторії моніторингу якості, безпеки кормів та сировини Інституту кормів та сільського господарства Поділля НААН визначається ступінь контамінації кормів спорами грибів, а імуноферментним методом присутність в них продуктів життєдіяльності грибів мікотоксинів. Методика роботи 3 аналізатором «Sunrise» та тестсистемами виробництва компанії «Neogen Corporation», дозволяють визначати шість найбільш поширених мікотоксинів: суму афлотоксинів (B1, B2, G1, G2, та інші); дезоксиніваленон (ДОН); зеараленон (ЗЕА); фумонізин; охратоксин А (ОТА); Т-2 токсин.

Аналізуючи отримані результати зроблено висновки, що від $21 \%$ до $45 \%$ зерна злакових культур, що використовується як кормова сировина, може бути забруднене афлатоксином. Цей мікотоксин насамперед пошкоджує печінку, орган який виконує детоксикацію токсичних речовин. Найвищий його вміст 0,21мг/кг виявлений у зерні кукурудзи, це більше ніж у два рази від допустимого рівня. Відсоток заражених зразків зерна цієї культури найвищий 45\%. Найменший процент зразків, які містили перевищену кількість афлотоксину, порівняно з допустимим рівнем, у зерні пшениці. Прикро також і те, що майже половина досліджених зразків комбікорму для птиці і $37 \%$ комбікорму для свиней були також забруднені цим мікотоксином.

Дезоксиніваленон не менш токсичний ніж його попередник, його ще називають вомітоксин, оскільки він викликає сильну діарею та відмову від споживання кормів тваринами. Найбільший відсоток зараженості цим мікотоксином, за отриманими даними, у зерні кукурудзи (більше 42\%). Кількість заражених зразків вівса дезоксиніваленоном на 4,5\% більша ніж афлатоксином, а зразків комбікорму для птиці у два рази менша. 354 зразків комбікорму для свиней у 18 вміст цього мікотоксину вищий у 1,2 рази порівняно 3 допустимим рівнем.

Іноземні спеціалісти відмічають, що перевищення зеараленону на $200-300 \mathrm{ppb}$ (тобто 0,2 - 0,3 мг/кг) уже привід для тривоги [2]. За показниками нормативних документів допустимий рівень цього мікотоксину не повинен перевищувати у зерні злакових та комбікормах для птиці і свиней 2,0-3,0 мг/кг. Близько половини проаналізованих нами зразків зерна кукурудзи містили зеараленон в кількості, яка була вища допустимого рівня на $17 \%$, тобто на 0,2-0,5мг/кг. Причому 
найнижчий показник вмісту цього мікотоксину майже вдвічі вищий від значення, яке дозволено у країнах СС. Як з'ясувалося, 40\% досліджуваних зразків комбікорму для птиці і $37 \%$ зразків комбікорму для свиней містили у своєму складі вищий на 6-11\% від допустимого рівня вміст зеараленону.

Токсин Т-2 є дуже токсичним мікотоксином, який виробляється грибами Fusarium і зустрічається у невеликій кількості кормів (менше 10\%). Він викликає зниження засвоєння кормів, гастроентерити, внутрішні крововиливи, а також впливає на синтез білку і знижує імунітет тварини. По результатам наших досліджень даний мікотоксин присутній у зерні злакових культур i його перевищення досягає $0,02-0,05$ мг/кг порівняно 3 допустимим рівнем 0,2 мг/кг. Лише у зерні кукурудзи зустрічалися зразки в яких його рівень був у три рази вищий. 354 зразків комбікорму для птиці чотири мали вміст Т-2 токсину від 0,21 до 0,31 мг/кг і лише один 0,54 мг/кг.

Важливо пам'ятати, що в сумі дія цих токсичних речовин на організм тварин та ії продуктивність набагато сильніша. I саме основне, що присутні у кормах можуть потрапляти у тваринницьку продукцію, при споживанні якої організм людини зазнає значного негативного впливу.

\section{Література:}

1. Энсмингер М.Е., Олдфилд Дж.Е., Хейнеманн В.В. Корма и питание. Перевод второго издания 1990 года. Издательская компанія Энсмингера 648 Вест Сиерра Авеню П.О. 429 Кловис. Калифорния, 93612, США. 1990. 974c.

2. Гібриди кукурудзи: грані проблеми / В. М. Гаврилюк та ін. Насінництво. 2015. № 3/4. С. 4-7.

3. Малінін О., Куцан О., Шевцова Г., Семеріна О. Мікотоксикологічний моніторинг концентрованих кормів лісостепу України. Тваринниитво Украӥни. 2003. N 12. C. 26-28.

4. Singh N., Baxi K.K., Jand S.K. Prevalence of different poultry diseases in relation to mycotoxins in poultry feed// «Proceedings XX World's Poultry Congress, New Dehli, India, 2-5 September, 1996». 1996. V. 2.-P.599-603].

5. Державний стандарт України ДСТУ 3570-97 Зерно фуражне, продукти його переробки, комбікорми. Методи визначення токсичності. Київ. ДЕРЖСТАНДАРТ. 1997. 15с. 